Marek Kita

Uniwersytet Papieski Jana Pawła II w Krakowie

\title{
Sobór Wszechprawosławny w relacji do II Soboru Watykańskiego
}

Zgodnie z cytowanym przez Yves'a Congara aforyzmem metropolity Andrija Szeptyckiego, chrześcijański Wschód „różni się od Zachodu nawet w tych kwestiach, w których nie ma między nimi żadnej różnicy" ${ }^{\prime}$. Inny cytowany przez wspomnianego autora teolog, Theodore de Régnon, stwierdzał z kolei, że Kościoły grecki i łaciński są dwiema siostrami pielęgnującymi wzajemną relację miłości i utrzymującymi rodzinną więź, ale mieszkającymi każda na własnym gospodarstwie ${ }^{2}$. Podejmując, a zarazem modyfikując obie powyższe metafory, można powiedzieć, że niewątpliwe rodzinne podobieństwo katolicyzmu i prawosławia absolutnie nie jest bliźniacze - zarówno gdy chodzi o powierzchowność oraz charakter, jak i sposób urządzenia konfesyjnego „mieszkania”. Ta fascynująca prawidłowość zdaje się oddziaływać także w przypadku dwóch epokowych przedsięwzięć, jakich podjęły się Kościoły w swej najnowszej historii - zwołania wyjątkowego soboru na Watykanie

${ }^{1}$ Y. Congar, Wierzę w Ducha Świętego, t. 3: Rzeka życia płynie na Wschodzie i na Zachodzie (Ap 22, 1), tłum. L. Rutowska, Warszawa 1996, s. 10.

${ }^{2}$ Zob. tamże. 
oraz zapoczątkowania prac nad jeszcze bardziej chyba wyjątkowym Soborem Wszechprawosławnym. Jednak wszystkie różnice, które wypada uszanować, nie mogą przesłonić podobieństw świadczących o pokrewieństwie tożsamym ze wspólnotą inspiracji, narodzeniem z jednego Ducha i napojeniem tymże Duchem Ojca, działającego „ponad wszystkimi, przez wszystkich i we wszystkich” (por. J 3, 8; 1 Kor 12, 13; Ef 4, 4-6).

\section{„Modernistyczna” prehistoria}

Choć nie sposób mówić o bezpośrednim związku oficjalnych inicjatyw prowadzących po stronie katolickiej do Vaticanum II, a w świecie prawosławnym do trwających aktualnie przygotowań soborowych, z tendencjami dochodzącymi do głosu u progu epoki współczesnej na styku „świeckiej” kultury filozoficzno-naukowej i „wysokiej” kultury kościelnej - to zarazem powiązanie przynajmniej rzymskiej „nowej Pięćdziesiątnicy” z inspiracjami płynącymi od ruchu modernistycznego raczej nie ulega wątpliwości ${ }^{3}$. Sformułowana przez arcybiskupa Lefebvre'a i podtrzymywana przez jego zwolenników diagnoza soborowych reform jako wyrazu „modernizmu” nie jest pozbawiona podstaw, problematyczna jest tylko towarzysząca jej kwalifikacja teologiczna ${ }^{4}$. Spoglądając na zjawisko katolickiego modernizmu nie przez okulary przesadnej (choć do pewnego stopnia usprawiedliwionej) obawy, jaka opanowała Piusa X i znalazła ujście w encyklice Pascendi Dominici gregis (oraz wywołanej przez nią kampanii inkwizycyjnej) ${ }^{5}$, lecz przez

${ }^{3}$ Zob. K. Schatz, Sobory powszechne. Punkty zwrotne w historii Kościoła, tłum. J. Zakrzewski, Kraków 2002, s. 258-259.

${ }^{4}$ Zob. M. Kita, Rosyjski „prawosławny modernizm” i ekumeniczna ortodoksja. Refleksja teologiczno-fundamentalna, „Kultura i Wartości” 2015, nr 14, s. 133.

${ }^{5}$ Zob. J. Kracik, Antymodernistyczna kampania, „Znak” (2002) nr 7 (566), s. 31, 33. Por. T. Dzidek, P. Sikora, Historyczne koncepcje teologii, [w:] Teologia fundamentalna, t. 5: Poznanie teologiczne, red. T. Dzidek, Ł. Kamykowski, A. Napiórkowski, Kraków 2006, s. 43. 
pryzmat uczciwych badań historyczno-teologicznych, można rozróżnić nie tylko „radykalne”, lecz również „umiarkowane” wersje tej bynajmniej nie jednolitej postawy intelektualnej ${ }^{6}$. Dokonania „umiarkowanych modernistów” w rodzaju Blondela, Lagrange'a, Laberthonnière'a czy Duchesne'a pozostawały równie uprawnionymi przejawami twórczej partycypacji w żywej tradycji wiary, jak swego czasu dorobek Klemensa z Aleksandrii, Tomasza z Akwinu czy rodzącego się Towarzystwa Jezusowego ${ }^{7}$ - faktycznie przygotowując grunt pod (także niejednorodne) nowe syntezy filozoficzne i teologiczne autorów epoki soborowej (jak Maritain, Teilhard de Chardin, Congar, de Lubac, Rahner), których myśl oddziaływała na ojców II Soboru Watykańskiego.

Co ciekawe, u korzeni odnowy teologii katolickiej w dobie Vaticanum II znalazły się między innymi impulsy płynące ze środowisk emigracyjnych myślicieli rosyjskich działających we Francji ${ }^{8}$, których przynajmniej pierwsze pokolenie reprezentowało w większości „umiarkowaną” wersję prawosławnego modernizmu z nurtu tzw. renesansu filozoficzno-religijnego ${ }^{9}$. Notabene sam ów nurt, jakkolwiek w intencji swych protagonistów miał wyrażać ducha wschodniego chrześcijaństwa, był w istocie (przy całym rosyjskoprawosławnym zabarwieniu) swoistą syntezą treści wschodnich i zachodnich, niemieckiej filozofii romantycznej z elementami orientalnej patrystyki oraz tradycji dawnej Rusi ${ }^{10}$. Fascynujący, choć paradoksalny przykład wymiany darów między poszukującą

${ }^{6}$ Zob. T. Dzidek, Wpływ modernizmu na współczesną teologię, „Znak” (2002) nr 7 (566), s. 57-58.

7 Zob. L. Kołakowski, Uwaga o modernizmie, „Znak” (2002) nr 7 (566), s. 14.

${ }^{8}$ Zob. np. J. Puyo, Życie dla prawdy. Rozmowy z ojcem Congarem, tłum. A. Paygert, Warszawa 1982, s. 66-67, 75. Por. A. Walicki, Zarys myśli rosyjskiej od oświecenia do renesansu filozoficzno-religijnego, Kraków 2005, s. 783.

${ }^{9}$ Zob. M. Kita, Rosyjski „prawosławny modernizm”..., dz.cyt., s. 130, 133-136. Por. S. Mazurek, Rosyjski renesans religijno-filozoficzny. Próba syntezy, Warszawa 2008, s. 11.

${ }^{10}$ Zob. M. Kita, Logos większy niż ratio. Dwa świadectwa chrześcijańskiego modelu racjonalności u progu epoki wspótczesnej, Kraków 2012, s. 40-42, 67. 
teologią katolicką i prawosławną stanowi krążenie inspiracji dotyczących pojmowania katolickości między Johannem Adamem Möhlerem (1796-1838) i osobiście zdecydowanie antyekumenicznym Aleksiejem Stiepanowiczem Chomiakowem (1804-1860) oraz Yves'em Congarem (1904-1995). Przy tym stymulowana przez „słowianofilów” (i dojrzewająca w dyskursie zarówno teologów „modernizujących”, jak i „neopatrystycznych”) ${ }^{11}$ odnowa „komunijnej” wizji eklezjologii i ortodoksji (dzięki koncepcji „soborowego” trwania w Prawdzie, którą się „charyzmatycznie przeżywa” w miłości, z inspiracji Ducha danego Kościołowi jako zhierarchizowanej, lecz braterskiej wspólnocie) nie tylko wzbogaciła, po okresie niepozbawionej zmagań recepcji ${ }^{12}$, oficjalną teologię prawosławia, ale też zaowocowała możliwą ambiwalencją postaw w odniesieniu do ewentualnego soboru ogólnego ${ }^{13}$. O ile na gruncie katolicyzmu przyswajanie idei „soborowości” pomogło w rehabilitacji kolegialności biskupiej oraz rozwinięciu teologii ludu Bożego, o tyle zbyt radykalna wersja tej idei może osłabiać koncyliarne dążenia prawosławne - jednak w jej przyswojonej ostatecznie postaci „umiarkowanej" uznaje się jak najbardziej zgromadzenia soborowe różnych szczebli (aż po najwyższy) za właściwe, choć nie jedyne, przejawy najgłębszej struktury Kościoła ${ }^{14}$.

W każdym razie, „modernistyczny” program wyartykułowany przez jednego z głównych prekursorów „rosyjskiego renesansu” Władimira Sołowjowa (1853-1900): „uzasadnić wiarę naszych ojców, wprowadzając ją na nowy stopień rozumnej świadomości"15, może zasadniczo inspirować dążenia do prawosławnego aggiornamento. Wprawdzie charakterystyczne przywiązanie wschodniego

\footnotetext{
${ }^{11}$ Zob. NSO, s. 32-39.

${ }^{12}$ Zob. A. Walicki, Zarys myśli rosyjskiej..., dz.cyt., s. 177-178, 784.

${ }_{13}$ Zob. NSO, s. 41.

${ }^{14}$ Zob. tamże, s. 69. Por. Bóg żywy. Katechizm Kościoła Prawosławnego, oprac. zespół wiernych prawosławnych, Kraków 2001, s. 369-371.

${ }_{15}$ Собрание сочинений Владимира Сергеевича Соловьева, том IV, Санкт-Петербург 1901-1907, s. 214.
} 
chrześcijaństwa do dziedzictwa „świętych Ojców” stanowi dla wielu wyznawców (hierarchów, mnichów i świeckich) przeszkodę w tej kwestii - rodząc wręcz postawy integrystyczne ${ }^{16}$ - jednak istnieją w łonie prawosławia poważne autorytety wyznające „umiarkowanie modernistyczne" (czyli po prostu tradycyjne w zdrowy sposób, nie konserwatywny, lecz apostolsko-charyzmatyczny) rozumienie ortodoksji. Metropolita Kallistos Ware uczy, że tradycja wiary pozostaje „życiem Ducha Świętego w Kościele” i dlatego jej prawosławne pojmowanie „nie jest statyczne, lecz dynamiczne” ${ }^{17}$. Tenże uznany przywódca kościelny i autorytet duchowy stwierdza wprost: „Tradycja ciągle przyjmuje nowe formy i postacie, które uzupełniają stare nie usuwając ich. Prawosławni często wyrażają się tak, jak gdyby okres dogmatycznych sformułowań dobiegł już końca, ale tak jednak nie jest. Być może jeszcze za naszych czasów zbierze się sobór powszechny i Tradycja wzbogaci się o świeże wyrażenia wiary"18.

Oczywiście praktyczne posunięcia w kierunku przeprowadzenia (w przypadku katolików) i przygotowania (na gruncie prawosławnym) dosyć oryginalnego w swych motywacjach (o czym poniżej) zgromadzenia biskupiego kolegium w wymiarze globalnym należały do wysokich hierarchów obu Kościołów. Również tutaj dają się zaobserwować pewne, niebędące identycznością, podobieństwa okoliczności oraz zamierzeń promotorów owych akcji.

\section{Geneza watykańskiej niespodzianki}

Jakkolwiek szeroko rozpowszechniona i mająca podstawę w wypowiedziach samego Jana XXIII wersja opowieści o genezie Vaticanum II głosi, że pomysł zwołania soboru pojawił się w papieskim umyśle

\footnotetext{
${ }^{16}$ Zob. np. wywiad Dawida Gospodarka z dr. Pawłem Wróblewskim Nie chcemy prawosławnego Vaticanum II, http://stacja7.pl/wiara/nie-chcemy-prawoslawnegovticanum-ii (13.1.2016).

${ }^{17}$ K. Ware, Kościół prawosławny, tłum. W. Misijuk, Białystok 2002, s. 221.

18 Tamże.
} 
wskutek nagłego impulsu natchnienia ${ }^{19}$, to jednak ustalenia badaczy komplikują ten prosty obraz ${ }^{20}$. Istnieją dane o prowadzonych dyskretnie już w trakcie konklawe, oraz od samego początku pontyfikatu, rozmowach nowego biskupa Rzymu z różnymi osobami na temat zamiaru, jakim miał zaskoczyć świat niecałe trzy miesiące po swym wyborze. Mimo wszystko te pozornie konkurencyjne wizje dojrzewania odnowicielskiego zamysłu i rozbłysku charyzmatycznej inspiracji nie muszą się wykluczać. Dobry Papież Jan (którego ewangeliczna prostota bynajmniej nie oznaczała „świętej naiwności") miał za sobą między innymi karierę seminaryjnego wykładowcy historii i prywatne studia nad archiwum św. Karola Boromeusza, dokumentującym okres kościelnej reformy po Soborze Trydenckim a także trudne osobiste zmagania o utrzymanie się na wąskiej via media między modernistycznym fermentem a ortodoksją pojmowaną statycznie ${ }^{21}$. W takim stanie rzeczy rozmyślania o uzdrowieniu Kościoła wydają się rzeczą naturalną. Jednocześnie Angelo Roncalli pozostawał człowiekiem pokornej modlitwy w duchu ignacjańskim ${ }^{22}$, zorientowanym na „bezpośrednią” (choć obiektywizowaną w rozeznaniu) wewnętrzną komunikację z Bogiem ${ }^{23}$. Skonkretyzowanie się pomysłu zwołania nowego soboru mogło więc faktycznie zadziwić samego pomysłodawcę, nie przestając być owocem wcześniejszych teoretycznych rozważań takiej możliwości, a dyskretne konsultacje ze współpracownikami mogły być traktowane jako dialog z samym Bogiem w procesie rozeznawania odkrytej w sobie intuicji.

Słynne wystąpienie z 25 stycznia 1959 roku, gdy „przejściowy papież" wyjawił publicznie swój przełomowy zamiar, wywołało pewien

\footnotetext{
${ }^{19}$ Por. J. Święcki, Jan XXIII. Wypróbowany święty, Kraków 2014, s. 169.

${ }^{20}$ Zob. K. Schatz, Sobory powszechne..., dz. cyt., s. 267-268.

${ }^{21}$ Zob. M. Kita, Boży człowiek Jan, „Znak” (2006) nr 1 (608), s. 99-101 (artykuł stanowi streszczenie liczącego ponad pięćset stron biograficznego studium Petera Hebblethwaite'a Pope John XXIII, Shepherd of the Modern World (Wyd. Doubleday, Garden City, N.Y., 1985). Por. J. Święcki, Jan XXIII..., dz. cyt., s. 43-44, 51-56.

${ }^{22}$ Zob. J. Święcki, Jan XXIII..., dz. cyt., s. 31-36, 93, 96-97, 193-203.

${ }^{23}$ Zob. Ignacy Loyola, Ćwiczenia duchowe, 15.
} 
szok. Niemniej idea kolejnego soboru, na przekór opinii kardynała Billota z 1920 roku o zakończeniu ery biskupich zgromadzeń wskutek zdefiniowania papieskiej nieomylności ${ }^{24}$, nurtowała w zaciszu Pałacu Apostolskiego kilku poprzedników Jana ${ }^{25}$. Rozważał ją Pius XI, myślący o dokończeniu przerwanych obrad Vaticanum I oraz zasięgający w tej sprawie (w roku 1923) poufnych opinii światowego episkopatu (mimo przewagi głosów pozytywnych projekt pozostał w zawieszeniu). Następnie Pius XII, z inicjatywy dwóch późniejszych liderów frakcji konserwatywnej soboru - kardynała Ruffiniego i biskupa (a wkrótce także kardynała) Ottavianiego - zlecił nawet przeprowadzenie prac przygotowujących to wydarzenie. Zarazem posunięty już wówczas w latach papież nie czuł się na siłach, by na dobre puścić w ruch soborową machinę, wyrażając w prywatnych rozmowach oczekiwanie, że zrobi to jego następca.

\section{Prawosławny „adwent” soborowy}

Jeśli chodzi o wyczekiwany nowy Sobór Wszechprawosławny, to u początków idei jego zwołania znalazła się Encyklika patriarchy Joachima III oraz Synodu Kościoła Konstantynopolitańskiego do wszystkich Kościołów prawosławnych z 12 czerwca 1902 roku, wzywająca do poszukiwania odpowiednich dróg realizacji jedności wewnątrz prawosławia oraz w perspektywie Kościoła powszechnego ${ }^{26}$. „Siostrzane Cerkwie" odniosły się do zawartych w tym dokumencie propozycji cyklicznych konferencji na temat aktualnych problemów kościelnych bez specjalnego entuzjazmu. Gdy jednak w roku 1920 Encyklika Kościoła w Konstantynopolu do wszystkich Kościołów świata jeszcze dobitniej wyartykułowała zaproszenie do kontaktów, dialogu, solidarności i współpracy w ramach całej ekumeny chrześcijańskiej, rumuński metropolita Miron Cristea za zgodą Świętego Synodu

\footnotetext{
${ }^{24}$ Zob. K. Schatz, Sobory powszechne..., dz. cyt., s. 258.

${ }^{25}$ Zob. tamże, s. 265-267.

${ }^{26}$ Zob. NSO, s. $139-140$.
} 
swego Kościoła rozesłał do pozostałych Cerkwi list z sugestią zwołania soboru lub konferencji wszechprawosławnej ${ }^{27}$. Trzy lata później patriarsze Konstantynopola Melecjuszowi IV udało się zgromadzić w murach Drugiego Rzymu uczestników kongresu prawosławnego poświęconego problematyce dyscypliny kościelnej i kalendarza liturgicznego, lecz na zgromadzeniu tym zabrakło pełnej reprezentacji światowego prawosławia - w tym przedstawicieli patriarchatów wchodzących w skład starożytnej „pentarchii”"28. Owocem kongresu, obok reformy kalendarza juliańskiego, stał się bardzo już konkretny postulat zwołania na rok 1925 (czyli w 1600. rocznicę Soboru Nicejskiego I) zgromadzenia soborowego wszystkich Kościołów prawosławnych.

Chociaż ambitny zamysł się nie powiódł, idea soboru zaczęła absorbować kolejne ważne gremia: patriarchów i Święte Synody poszczególnych Cerkwi, wybitnych teologów, a nawet władze państwowe niektórych krajów o tradycyjnie prawosławnej populacji ${ }^{29}$. Spierano się o lokalizację tak ważnego spotkania (w grę wchodziły Święta Góra Athos, Jerozolima, ale także serbskie miasto Niš skąd pochodził Konstantyn Wielki, oraz Moskwa), ustalano również listę tematów do poruszenia w trakcie obrad. Tym ostatnim zajęła się zwłaszcza Konferencja Przygotowawcza w monasterze Watopedi na górze Athos w 1930 roku. Podczas Kongresu Teologów Prawosławnych w Atenach w roku 1936 toczyły się debaty na temat przyszłego soboru, jednak uczestnicy tego spotkania uznali cały projekt za przedwczesny. Pod koniec lat 40. XX wieku intensywne zabiegi wokół organizacji zamierzonego soboru w Moskwie podejmował Rosyjski Kościół Prawosławny, jednak te inicjatywy były naznaczone tendencjami nacjonalistycznymi (w duchu idei „Trzeciego Rzymu”) i mocarstwowymi (ateistyczny reżim chciał dyskontować pozycję rosyjskiej Cerkwi we wschodnim chrześcijaństwie). W następnej

\footnotetext{
${ }^{27}$ Zob. tamże, s. 141-143.

${ }^{28}$ Zob. tamże, s. 144.

${ }^{29}$ Zob. tamże, s. 145-160.
} 
dekadzie ideę soboru wszechprawosławnego promował z wielkim zaangażowaniem charyzmatyczny patriarcha Konstantynopola Atenagoras (1886-1972). Doprowadził on do spotkania przedstawicieli niemal całego prawosławnego świata na Pierwszej Konferencji Wszechprawosławnej na Wyspie Rodos w roku 1961, która pociągnęła za sobą dwa kolejne analogiczne zjazdy w latach 1963 i $1964^{30}$. Czwarta Wszechprawosławna Konferencja w Chambésy koło Genewy (1968) pozwoliła skonkretyzować program przygotowań do soboru, a następnie szwajcarskie Centrum Patriarchatu Ekumenicznego gościło w latach 1976, 1982, 1986, 2009 i 2015 kolejne Wszechprawosławne Konferencje Przedsoborowe.

\section{Okoliczności i promotorzy przygotowań}

Zarówno w przypadku zrealizowanych już katolickich projektów soborowych, jak i w sytuacji powoli dojrzewających projektów prawosławnych, mamy do czynienia z genezą sięgającą początków minionego stulecia - i choć nie da się mówić o identyczności położenia naszych Kościołów, to jednak niektóre okoliczności wydają się w pewien sposób analogiczne. Soborowe idee nurtowały z jednej strony rzymskich papieży, z drugiej zaś patriarchów ekumenicznych, zatem przy całej nieprzystawalności statusu tych urzędów w ich własnych kontekstach eklezjalnych można stwierdzić, że promotorami soboru pozostawało w obu wypadkach hierarchiczne (a nie polityczne, jak w pierwszym tysiącleciu) centrum „katolickiej” (jakkolwiek niejednolicie rozumianej) jedności. Jeśli to kościelne „uwewnętrznienie" koncyliarnej inicjatywy jest normalne dla rzymskiego katolicyzmu, ukształtowanego w ciągu drugiego millenium, to dla wschodniego prawosławia, pielęgnującego tradycję Siedmiu Soborów, stanowi nieuniknione, lecz rodzące problemy novum ${ }^{31}$. Przy tym oba wspomniane ośrodki duchowego (w przypadku Rzymu

\footnotetext{
${ }^{30}$ Zob. tamże, s. 161-199.

${ }^{31}$ Zob. NSO, s. 73-74.
} 
również jurysdykcyjnego) autorytetu funkcjonowały w warunkach wymuszonego przez świecką politykę ogołocenia ze „środków bogatych". Papiestwo za czasów Piusa XI (oraz, rzecz jasna, za pontyfikatów jego następców) nie posiadało już Państwa Kościelnego, natomiast patriarcha Konstantynopola za czasów Joachima III stracił prerogatywy cywilno-administracyjne posiadane w Imperium Osmańskim (jako głowa prawosławnego milletu). Jeszcze słabsza pozycja w ramach układu politycznego przypadła w udziale patriarchom ekumenicznym okresu Republiki Tureckiej ${ }^{32}$.

Podobnie, choć również zdecydowanie mutatis mutandis, jawią się postacie pełnych szczególnej charyzmy animatorów finału katolickich planów soborowych oraz „przedostatniego” etapu przygotowań do Soboru Wszechprawosławnego. Mówi się o profetyzmie Jana XXIII ${ }^{33}$, ale także o patriarsze Atenagorasie jako „starcu" - przewodniku duchowym ${ }^{34}$, wizjonerze i proroku ${ }^{35}$. Wyraźnie zbieżne są konteksty teologiczne obu projektów: inicjatywa zwołania biskupiego kolegium nie stanowiła u katolików i nie stanowi u prawosławnych reakcji na jakiś ekstremalnie palący problem natury dogmatycznej lub dyscyplinarnej, lecz wynika z poczucia konieczności dostosowania życia kościelnego (w duchu przywołanego wyżej „umiarkowanego modernizmu” dynamicznej ortodoksji) do nowych uwarunkowań historycznych. Także w tej kwestii daje się jednak zaobserwować szereg różnic dotyczących charakteru aktualnie stojących przed Kościołami wyzwań oraz sposobu ich opisywania i podejmowania.

${ }^{32}$ Zob. A. Riccardi, Una vita complessa, [w:] Atenagoras, Chiesa ortodossa e futuro ecumenico. Dialoghi con Olivier Clément, Brescia 1995, s. 376-377.

${ }^{33}$ Zob. L. F. Capovilla, Giovanni XXIII: „Se la Chiesa si ripresenterà giovane e pura...”, [w:] G. F. Svidercoschi, Inchiesta sul Concilio. Parlano i protagonisti, Roma 1985, s. 17-18.

${ }^{34}$ Zob. A. Riccardi, Una vita complessa, dz. cyt., s. 379.

${ }^{35}$ Zob. O.Clément, Pamiętniki nadziei. Rozmowa z Jeanem-Claudem Noyer, tłum. M. Żurowska, Poznań 2008, s. 131. 


\section{Katolickie plany wobec soboru}

Gdy za pontyfikatu Piusa XII prowadzono w tajemnicy przed opinią publiczną wstępne przygotowania do nowego soboru, w łonie powołanej do tych prac komisji ujawniły się dwie wizje przyszłego zgromadzenia biskupów ${ }^{36}$. Zasadniczą intencją Stolicy Apostolskiej było kolegialne wyartykułowanie osądu na temat rozmaitych zjawisk zachodzących we współczesnym świecie, a także sformułowanie wezwań dotyczących życia społeczeństw i funkcjonowania społeczności kościelnej oraz decyzji o modernizacji pewnych eklezjastycznych struktur. Jednak część papieskich współpracowników widziała sobór jako wydarzenie o charakterze głównie reprezentacyjnym, manifestację jedności i forum dla wygłoszenia zgodnej deklaracji ideowej ad extra, podczas gdy faktycznym laboratorium reform byłaby (owszem, po wysłuchaniu opinii ojców soborowych) Kuria Rzymska. W projekcie inspirowanym duchem papieskiego centralizmu (i logiką Vaticanum I) ${ }^{37}$ zakładano urządzenie w miarę krótkiego zjazdu, starannie wcześniej przygotowanego. Z kolei inna część komisji, mając wzgląd na tradycję Kościoła, optowała za zgromadzeniem całkowicie wolnym, samostanowiącym o sobie i debatującym swobodnie. Co najwyżej dla usprawnienia prac wyjątkowo licznego gremium proponowano obradowanie etapami, w reprezentatywnych podzespołach. Wydaje się godne uwagi, że zachowujący na co dzień dość hieratyczną postawę Pius XII popierał właśnie to drugie rozwiązanie.

Przed soborem oraz w czasie jego trwania dochodziły do głosu oczekiwania i pragnienia zarówno hierarchów (bynajmniej zresztą nie jednomyślnych, co miały unaocznić światu późniejsze obrady), jak i rozmaitych nurtów nowoczesnego katolicyzmu ${ }^{38}$, realizujących

\footnotetext{
${ }^{36}$ Zob. K. Schatz, Sobory powszechne..., dz. cyt., s. 266-267.

${ }^{37}$ Por. B. Sesboüé, Ch. Theobald, Słowo zbawienia, [Historia dogmatów 4], tłum. P. Rak, Kraków 2003, s. 405.

${ }^{38}$ Zob. K. Schatz, Sobory powszechne..., dz.cyt., s. 258-265. Por. B. Sesboüé, Ch. Theobald, Słowo zbawienia, dz.cyt., s. 387-388.
} 
podwójne dążenie do dialogu ze światem współczesnym i zgłębiania odkrywanych na nowo źródeł własnej tradycji. Katolicyzm społeczny, odrodzenie świadomości eklezjalnej („budzenie się Kościoła w duszach" według znanej frazy Guardiniego), nowe prądy teologiczne (teologia kerygmatyczna, nouvelle theologie), ruch biblijny, ruch liturgiczny oraz dojrzewający katolicki ekumenizm przygotowywały grunt pod episkopalne otwarcie na „nową Pięćdziesiątnicę” oraz entuzjastyczną recepcję soborowych proklamacji Jana XXIII w szerokich kręgach katolików manifestujących swój sensus fidei ${ }^{39}$. Encyklika Dobrego Papieża Jana Ad Petri cathedram z roku 1959 wskazywała, że główny cel nowego soboru „polega na tym, aby bardziej uwypuklić rozwój katolickiej wiary, odnowić chrześcijańskie życie wiernych i dostosować kościelną dyscyplinę do warunków naszych czasów" ${ }^{40}$, a także dać impuls ekumeniczny w postaci „łagodnego zaproszenia” innych chrześcijan (określanych jeszcze nieco niefortunnie, mimo dobrych intencji, mianem „odłączonych od Stolicy Apostolskiej”) do szukania i odnajdowania jedności, o którą modlił się Chrystus w Wieczerniku. Jeśli taki sposób wyrażania ekumenicznego otwarcia nosi na sobie piętno idei „wzywania niekatolików do powrotu”, to jednak osobiste intuicje samego autora encykliki kierowały go ku pojednaniu bez wytykania sobie nawzajem win i błędów oraz bez odmawiania chrześcijanom innych wyznań członkostwa w jednym Kościele Chrystusa ${ }^{41}$. Ten punkt widzenia dojdzie ostrożnie do głosu w słynnym eklezjologicznym sformułowaniu subsistit in z Konstytucji dogmatycznej Lumen gentium (nr 8), wskazującym (zgodnie z późniejszym wyjaśnieniem Jana Pawła II), że katolicyzm nie stwierdza poza swymi kanonicznymi granicami „eklezjalnej próżni” (encyklika Ut unum sint, 13) ${ }^{42}$.

${ }^{39}$ Zob. B. Sesboüé, Ch. Theobald, Słowo zbawienia, dz. cyt., s. 405.

${ }^{40}$ Cyt. za: J. Święcki, Jan XXIII..., dz. cyt., s. 168.

${ }^{41}$ Zob. K. Spink, Brat Roger, założyciel Taizé, tłum. A. Turowiczowa, Katowice 1992, s. $71,80-81$.

${ }^{42}$ Zarazem katolickie stanowisko w tej kwestii wciąż jest cyzelowane w toku dramatycznych nieraz dyskusji - por. M. Kita, Ekumenizm. Żyć z paradoksami, [w:] Chrześcijaństwo przed nami, red. J. Makowski, J. Salamon, Kraków 2008, s. 116. 
Ekumeniczne w nowy sposób (pokorny i profetyczny) ukierunkowanie zwoływanego soboru znalazło wyraz w zaproszeniu i konsultowaniu obserwatorów ze świata prawosławnego oraz Światowej Rady Kościołów, natomiast aspekt aggiornamento - relektury doktryny katolickiej w nowych uwarunkowaniach historycznych - wiązał się z przełomową „zmianą paradygmatyczną"43 w sprawowaniu magisterium. Otwierające obrady przemówienie Jana XXIII, zatytułowane Gaude Mater Ecclesia, prezentowało nowy sposób postrzegania świata, odmienny od katastroficznej perspektywy poprzedniego soboru, nacechowany ufnością wobec Boga kierującego historią oraz życzliwością wobec zanurzonych w tę historię ludzi. Proponowało też ojcom soborowym nową hermeneutykę tajemnicy wiary, uwzględniającą jej antropologiczne zakorzenienie i ukierunkowanie eschatologiczne, skoncentrowaną na recepcji nienaruszalnej prawdy bez absolutyzowania kulturowych form jej wyrazu, z duszpasterskim nastawieniem na służenie ewangelicznej przemianie świadomości współczesnego człowieka, powołanego do zbawienia. Oryginalny włoski tekst wystąpienia papieża został przez kurialistów w symptomatyczny sposób przeredagowany w ramach oficjalnej dokumentacji łacińskiej, co wskazuje na kłopot zachowawczo zorientowanych kręgów hierarchii z akceptacją hermeneutycznego zwrotu $^{44}$. W okresie posoborowym z kolei wciąż powraca kwestionowanie przez wojujących tradycjonalistów wiążącej mocy nauczania Vaticanum II w oparciu o fakt ,jedynie duszpasterskiego", a nie „doktrynalnego" charakteru jego wypowiedzi. Tymczasem właśnie programowe przemówienie papieża Jana nie tylko akcentuje niesprzeczność wspomnianych wymiarów magisterium, lecz w duchu „paradygmatycznej zmiany” wręcz proklamuje pastoralną formę magisterium nadzwyczajnego vel uroczystego ${ }^{45}$.

\footnotetext{
${ }^{43}$ Zob. B. Sesboüé, Ch. Theobald, Stowo zbawienia, dz. cyt., s. 406-411.

${ }^{44}$ Zob. tamże, s. 409, przyp. 24.

${ }^{45}$ Zob. tamże, s. 410, zwłaszcza przyp. nr 26.
} 
Gdy po śmierci charyzmatycznego promotora soboru kolejny biskup Rzymu, Paweł VI, wznawiał przerwane obrady, w jego przemówieniu znalazło się zwięzłe określenie ich celu, ujętego w czterech punktach: „uświadomienie sobie Kościoła (1); jego odnowienie (2); dojście do jedności wszystkich chrześcijan (3); wejście Kościoła w rozmowę ze światem współczesnym (4)" ${ }^{46}$.

\section{Plany i oczekiwania prawosławne}

Jeśli chodzi o formułowane na gruncie prawosławia oczekiwania pod adresem przyszłego Wielkiego i Świętego Soboru, to zostało już wyżej powiedziane, że począwszy od „przedwstępnych” inicjatyw patriarchy Joachima III z roku 1902 oraz Synodu Kościoła Konstantynopolitańskiego z 1920 roku - jak również od Kongresu Kościołów prawosławnych z roku 1923 - zarysowały się dwie zasadnicze kwestie: jedności w ramach ortodoksji „bizantyjskiej” i w perspektywie ekumenicznej oraz reform dyscyplinarnych (jak aktualizacja kalendarza liturgicznego i uregulowanie spraw powtórnych małżeństw owdowiałych duchownych, właściwego wieku do przyjęcia święceń, przeszkód małżeńskich, rozwodów, przepisów postnych ${ }^{47}$. Proponowana w kontekście niezrealizowanych planów na rok 1925 tematyka oczekiwanego soboru obejmowała ekumeniczne ujednolicenie kalendarza świąt paschalnych, problem zjednoczenia Kościołów chrześcijańskich, rewizję kanonów kościelnych i akceptację ksiąg symbolicznych ${ }^{48}$. Z kolei podczas Konferencji Przygotowawczej na górze Athos w roku 1930 wypracowano, z myślą o „pro-soborze” (do którego ostatecznie nie doszło), szesnastopunktowy plan debaty, obejmujący oprócz wspominanych już problemów m.in. kwestię formacji duchowieństwa, przywrócenia świetności życiu monastycznemu, ujednolicenia ksiąg liturgicznych, kościelnej

\footnotetext{
${ }^{46}$ Cyt. tamże, s. 414.

${ }^{47}$ Zob. NSO, s. 144.

${ }^{48}$ Zob. tamże, s. 145.
} 
procedury karnej i procedury wyboru biskupów, analizy sytuacji Kościoła w Ameryce, relacji do heretyków i schizmatyków oraz walki z ateizmem, utrwalania kultury prawosławnej i pielęgnowania sztuki bizantyjskiej ${ }^{49}$. Ważnym punktem podczas tejże konferencji pozostawała sprawa udziału w pro-soborze Rosyjskiego Kościoła Prawosławnego, znajdującego się w niezwykle trudnym położeniu pod rządami komunistycznego reżimu. Światu prawosławnemu zależało (tak wówczas, jak i później) na komunii z uciemiężonym Patriarchatem Moskiewskim, chociaż wspomniany patriarchat miał również stwarzać poważne problemy w toku starań o sobór, w związku ze swymi supremacyjnymi zapędami ${ }^{50}$.

Podczas Konferencji w Chambésy w roku 1968 wybrano z obszernego katalogu zagadnień, zaproponowanych Kościołom prawosławnym do refleksji przez Pierwszą Konferencję Wszechprawosławną na wyspie Rodos (1961), sześć tematów do przestudiowania w poszczególnych, imiennie wskazanych, lokalnych Kościołach autokefalicznych: kwestie źródeł Bożego Objawienia, pełniejszego udziału świeckich w liturgii i życiu Kościoła, przystosowania przepisów postnych do warunków współczesności, przeszkód małżeńskich, kalendarza liturgicznego i zasady „ekonomii eklezjalnej” ${ }^{51}$. W roku 1976, podczas kolejnej konferencji w Chambésy, zweryfikowano listę tematów proponowanych pod obrady przyszłego soboru, przedkładając ponownie do opracowania wskazanym Kościołom kwestie dotyczące problematyki zależności jurysdykcyjnych w diasporze prawosławnej, autokefalii i sposobu jej ogłaszania, autonomii (niezależności w mniejszym zakresie) i sposobu jej ogłaszania, uporządkowania dyptychów (spisów hierarchicznie uszeregowanych Cerkwi o uznanej kanoniczności, odczytywanych w trakcie Boskiej Liturgii), nowego kalendarza liturgicznego (z uzgodnioną ekumenicznie datą Wielkanocy), przeszkód małżeńskich, modyfikacji

\footnotetext{
${ }^{49}$ Zob. tamże, s. 149.

${ }^{50}$ Zob. tamże, s. 157-159.

${ }^{51}$ Zob. tamże, s. 171.
} 
przepisów postnych, relacji Kościołów prawosławnych z resztą chrześcijańskiej ekumeny oraz wkładu lokalnych Cerkwi w realizację ideałów pokoju, wolności, braterstwa i miłości między narodami, a także zniesienie dyskryminacji rasowej52. Sześć lat później, również w Chambésy, przyjęto dwa schematy „zadanych” przyszłemu soborowi konkretnych dokumentów: Przeszkody małżenskie i Zagadnienie kalendarza, natomiast po kolejnych czterech latach zatwierdzono tamże schematy: Znaczenie postu ijego zachowanie dzisiaj, Relacje Kościoła prawosławnego z całym światem chrześcijańskim, Kościót prawosławny a ruch ekumeniczny, oraz Wkład Kościoła prawosławnego $w$ realizację pokoju, sprawiedliwości, wolności, braterstwa i miłości między narodami oraz zniesienie dyskryminacji rasowej i innych ${ }^{53}$. Pozostają otwarte i są wciąż dyskutowane wspominane wcześniej problemy natury prawno-kanonicznej i eklezjologicznej.

\section{Efekty obrad Vaticanum II}

Sobór Watykański II stał się w pewien sposób, analogicznie do koncyliarnych zgromadzeń z Konstancji (1414-1418) i Bazylei (14311449), „soborem eksperckim”54, podczas którego dużą rolę odegrali teologiczni doradcy biskupów, którzy z kolei wykazywali wielką otwartość na odnowicielskie intuicje oraz na dialog w ramach episkopalnego kolegium ${ }^{55}$. Będąc zdecydowanie czymś więcej niż dopełnieniem wcześniejszego o niemal wiek Vaticanum I, sobór ten przyją, zgodnie z profetycznym zaproszeniem Jana XXIII i oczekiwaniami kościelnej „opinii publicznej”56, radykalnie odmienną niż poprzedni optykę (paradygmat „radości i nadziei”) oraz wzorzec przeżywania ortodoksji (otwartej na „newmanowski” uprawniony

\footnotetext{
${ }^{52}$ Zob. tamże, s. 181.

${ }^{53}$ Zob. tamże, s. 189, 198.

${ }^{54}$ Zob. K. Schatz, Sobory powszechne..., dz. cyt., s. 287-288.

${ }^{55}$ Zob. tamże, s. 296.

${ }^{56}$ Zob. tamże, s. 271-272, 282.
} 
rozwój, dynamicznej). W porównaniu z poprzednim soborem dokładnie odwrotnie rozłożyły się na Vaticanum II proporcje liczebności ojców „konserwatywnych” oraz „reformatorskich”, a zarazem całkowicie odmienny (pomimo parcia w kierunku zmian) okazał się klimat dyskusji i głosowań, podczas których z bezprecedensową gorliwością starano się przestrzegać „zasady moralnej jedności” i unikać bezwzględnej majoryzacji mniejszości soborowej ${ }^{57}$.

Efektem obrad stały się w pierwszym rzędzie konstytucje Sacrosanctum Concilium (o liturgii), Lumen gentium (dogmatyczna o Kościele), Dei verbum (dogmatyczna o Objawieniu) oraz Gaudium et spes (duszpasterska o Kościele w świecie współczesnym), a następnie dekrety Inter mirifica (o środkach społecznego przekazu), Orientalium Ecclesiarum (o katolickich Kościołach wschodnich), Unitatis redintegratio (o ekumenizmie), Christus Dominus (o zadaniach biskupów), Perfectae caritatis (o przystosowanej odnowie życia zakonnego), Optatam totius (o formacji kapłańskiej), Apostolicam actuositatem (o apostolstwie świeckich), Ad gentes divinitus (o działalności misyjnej) i Presbyterorum ordinis (o posłudze i życiu kapłanów), a także deklaracji Gravissimum educationis (o wychowaniu chrześcijańskim), Nostra aetate (o stosunku do innych religii) oraz Dignitatis humanae (o wolności religijnej). Przy całej otwartości kwestii długoterminowej recepcji tego bogatego w treść nauczania spowodowało ono nieodwracalny przełom „w teologii, w życiu wiary i w praktyce kościelnej” ${ }^{8}$, dotyczący afirmacji „historycznego myślenia”, dostrzegania hierarchii prawd dogmatycznych, zasadniczo chrystologicznej koncentracji wiary i pobożności, rozsądnego unaukowienia biblistyki przy jednoczesnym dowartościowaniu roli Pisma w refleksji i duchowości, odnowy życia liturgicznego oraz nobilitacji i aktywizacji świeckich i bardziej empatycznego, „indukcyjno-empirycznego" podejścia do „spraw światowych”.

${ }^{57}$ Zob. tamże, s. 283-285.

${ }^{58}$ K. Schatz, Sobory powszechne..., dz. cyt., s. 326. 


\section{Różnice w zbieżnościach}

Czy promotorom i zwolennikom przyszłego Soboru Wszechprawosławnego chodzi o to samo, co osiągnął Sobór Watykański II? Ton propozycji przedkładanych oficjalnie zdaje się dosyć ostrożny, a założenia skromniejsze, jednak główne obszary zainteresowania wydają się zbliżone. Nie należy przy tym zapominać, że w przededniu naszego katolickiego soboru przesyłane do Rzymu vota konsultowanych biskupów również brzmiały dosyć wstrzemięźliwie: pisano o wzmocnieniu pozycji biskupa diecezjalnego, uproszczeniu liturgii, odnowie stałego diakonatu, nieliczni sugerowali pogłębienie eklezjologii czy nauki społecznej - późniejszy rozkład sił „reformatorskich” i „konserwatywnych” jeszcze się wówczas w gronie przyszłych ojców nie ukształtował, a nawet początkowo przeważali w nim spadkobiercy potrydenckiego i ultramontańskiego „nieprzejednania” (optujący raczej za nowymi anatemami i kolejnymi dogmatami maryjnymi) ${ }^{59}$.

Jeśli zatem porównać tytuły dokumentów Vaticanum II i zestaw zaproponowanych w Chambésy, podczas Pierwszej Wszechprawosławnej Konferencji Przedsoborowej w roku 1976, tematów do podjęcia, to daje się stwierdzić analogiczny zamiar refleksji nad samookreśleniem danego Kościoła w relacji do reszty chrześcijańskiej ekumeny oraz całego świata „ludzi dobrej woli”, a także (o czym była już mowa) nad aktualizacją reguł życia kościelnego do realiów współczesnych. Zarazem w procesie o wiele dłuższego niż po stronie katolickiej, prawosławnego przygotowania - stanowiącego przy tym, paradoksalnie, w jakiejś mierze antycypację kolegialnego rozeznawania, „czas soborowy”60 - szereg ważnych zagadnień pozostaje w zawieszeniu, ze względu na trudności z uzgodnieniem stanowisk ${ }^{61}$. W porównaniu z widoczną rolą reformy liturgii w odnowie zapoczątkowanej przez Vaticanum II rzuca się w oczy prawosławna

\footnotetext{
${ }^{59}$ Zob. tamże, s. 269-270.

${ }^{60}$ Zob. NSO, s. 384.

${ }^{61}$ Zob. tamże, s. 384-385.
} 
powściągliwość w tej kwestii - uwarunkowana zapewne najgłębszym poszanowaniem szczególnego, właśnie liturgicznego charyzmatu tradycji wschodniej, podziwianego zresztą nieraz przez zachodnich chrześcijan. Jednak nawet afirmując w pełni i od wewnątrz prawosławny "geniusz filokaliczny" ${ }^{2}$, mistyczną celebrację teofanicznego piękna, można dostrzegać problem zastygnięcia w rytualizmie $^{63}$, a z drugiej strony nieprzystawalność do współczesnej mentalności (zwłaszcza młodych) „rozlewnych” liturgii odziedziczonych z tradycji ${ }^{64}$. Przykład nabożeństw Wspólnoty z Taizé, skądinąd inspirującej się częściowo wschodnimi formami pobożności, pokazywał prawosławnemu Francuzowi, Olivierowi Clémentowi, że istnieje możliwość odnalezienia „liturgii pięknej i prostej”65. Nawiasem mówiąc, legendarny rosyjski duszpasterz-męczennik epoki komunizmu, Aleksander Mień (1935-1990), świadomie i do pewnego stopnia heroicznie trwający w prawosławiu, z zachwytem odniósł się do nowej rzymskokatolickiej liturgii mszalnej Pawła VI, widząc w niej nawrót do prostoty rytu apostolskiego ${ }^{66}$. Wydaje się, że podobnie jak ,filokaliczny" obrządek bizantyjski dostarcza (razem z chorałem gregoriańskim) wzbogacających inspiracji np. cenionemu przez Clémenta dominikańskiemu liturgiście André Gouzesowi, tak również unikające wypaczających reformę ekscesów uproszczenie łacińskiej Służby Bożej w dobie Vaticanum II mogłoby natchnąć analogiczne (choć z pewnością nieidentyczne) przedsięwzięcia prawosławne.

Jeśli chodzi o wciąż niedopracowane wskutek rozbieżności poglądów kwestie autokefalii i uporządkowania dyptychów, to w świetle faktu, że jedną z kluczowych przeszkód pozostaje tu spór o interpretację roli Patriarchatu Ekumenicznego w prawosławiu ${ }^{67}$, wypada

${ }^{62}$ Zob. O. Clément, Pamiętniki nadziei..., dz. cyt., s. 209.

${ }^{63}$ Zob. tamże.

${ }^{64}$ Zob. tamże, s. 68.

${ }^{65}$ Por. O. Clément, Taizé. Szukanie sensu życia, tłum. M. Prussak, Poznań 1999, s. 47.

${ }^{66}$ Zob. Умное небо. Переписка протоерея Александра Меня с монахиней Иоанной (Ю.Н. Рейтлингер), Москва 2006, s. 332-333.

${ }^{67}$ Zob. NSO, s. 385. 
stwierdzić, że przed Kościołem wschodnim stoi szczególne zadanie przemyślenia w Duchu Świętym i braterskim dialogu problematyki prymatu. Jest to jakby odwrotność wyzwania, jakie podjęli ojcowie Soboru Watykańskiego II i z jakim zmaga się posoborowy katolicyzm aż do dziś (przy czym pontyfikat papieża Franciszka otworzył wyraźnie nowy etap, na którym depozytariusz uniwersalnego prymatu podjął się promowania z całą mocą episkopalnej i ogólnokościelnej kolegialności ${ }^{68}$. Zresztą trzeźwy ogląd prawosławnych realiów każe stwierdzić, że również na tym gruncie, wbrew głoszonemu ideałowi, przeżywanie eklezjologii eucharystycznej i soborowej komunijności pozostawia wiele do życzenia, ustępując raczej silnej hierarchizacji słabo współpracujących ze sobą autokefalii ${ }^{69}$. Bizantyjsko-słowiański Wschód niewątpliwie udzielił łacińskiemu Zachodowi cennej (i wciąż nie do końca odrobionej) lekcji „soborowości”, jednak sam lekarz także potrzebuje kuracji.

W kontekście uwidocznionej komplementarności okołosoborowych wyzwań - do których wypada dodać odzyskiwanie przez łacinników (dzięki impulsom pochodzącym od nouvelle theologie) duchowego i kontemplacyjnego wymiaru intelektualnego opracowania wiary (według wzorców patrystycznych) oraz otwarcie wschodnich ortodoksów na zdobycze krytycznej myśli nowoczesnej70 $\mathrm{i}$ zaangażowanie społeczno-polityczne w duchu międzyludzkiej solidarności oraz sprawiedliwości społecznej ${ }^{71}$ - powraca ekumeniczny aspekt eklezjalnej odnowy. Nasze Kościoły dialogują ze sobą, w jakiejś mierze się od siebie uczą oraz próbują sobie poradzić z nieszczęsną separacją. Można było zauważyć, że element restytucji jedności chrześcijan wciąż się przewijał zarówno w przedsoborowych inicjatywach patriarchów Konstantynopola, jak i w wypowiedziach zwołującego Vaticanum II papieża Jana, a także w epokowym dekrecie Unitatis

${ }^{68}$ Zob. A. Ivereigh, Prorok. Biografia Franciszka, papieża radykalnego, tłum. M. Masny, Bytom 2015, s. 425.

${ }^{69}$ Zob. O. Clément, Pamiętniki nadziei..., dz. cyt., s. 208.

${ }^{70}$ Zob. tamże, s. 208-209, oraz K. Ware, Kościół prawosławny, dz. cyt., s. 363.

${ }^{71}$ Zob. O. Clément, Pamiętniki nadziei, dz. cyt., s. 69-70. 
redintegratio. Jeśli porównać tekst tego ostatniego z proklamowanym w Chambésy dokumentem Kościót prawosławny a ruch ekumeniczny, można dostrzec analogiczne staranie o mądre wyważenie jednoczesnego zaakcentowania własnej samoświadomości eklezjalnej (zakładającej integralne przeżywanie jedności, świętości, katolickości i apostolskości) oraz otwarcia się na wspólnotę z innymi wyznawcami Chrystusa i Ewangelii. Kościół prawosławny okazuje się przy tym bardziej otwarty na partnerstwo w wymiarze praktycznym, przez członkostwo w Światowej Radzie Kościołów (której ideę zdaje się wręcz antycypować encyklika Patriarchatu Ekumenicznego z 1920 roku $)^{72}$, natomiast doktryna katolickiego soboru nieco mocniej, jakkolwiek niezwykle ostrożnie, wyraża (poprzez wspomniane już subsistit) uznanie partycypacji pozostałych chrześcijan w jednym Kościele Chrystusowym.

\section{Zamiast konkluzji}

Trudno o jednoznaczne podsumowanie, gdy mowa o przedsięwzięciu wciąż jeszcze pozostającym w fazie projektu, nawet jeśli do pewnego stopnia antycypowanym w trwającej już debacie przygotowawczej. Trudno także, będąc dzieckiem jednej z siostrzanych tradycji, wypowiadać się na temat przedsięwzięć podejmowanych w ramach tej drugiej w tonie nazbyt kategorycznym - a w każdym razie nie byłoby to grzeczne, ponieważ duchowe pokrewieństwo szczególnie zobowiązuje do okazywania szacunku. Prawosławni chrześcijanie mają prawo do swobodnego samookreślenia i zgodnej ze swoją wrażliwością teologiczno-kościelną reakcji na własne, ogólnochrześcijańskie i ogólnoświatowe problemy. Wolno jednak, w imię rodzinnej miłości i solidarności (a co za tym idzie - odpowiedzialności), mieć i wyrażać konkretne pragnienia oraz nadzieje, tym bardziej że przecież tęsknimy za doświadczeniem pełnej jedności, jakkolwiek niebędącej ujednoliceniem. Modlitwa w duchu

\footnotetext{
${ }^{72}$ Zob. NSO, s. 142.
} 
o. Couturiera o ,jedność, jakiej chce Chrystus, poprzez środki, jakie On wybiera", implikuje gotowość na niespodzianki, otwieranie się samemu na dyskretne Chrystusowe sugestie, słuchanie drugiej strony w przyjaznym towarzyszeniu, ze świadomością, że Pan przemawia w jej przeżyciach - a także dzielenie się uzyskiwanym rozeznaniem.

Zgodnie z wymową przywołanych na wstępie tego przedłożenia metafor przyszły Sobór Wszechprawosławny nie powinien i nie może być (a więc najpewniej nie będzie) dokładnym odwzorowaniem Soboru Watykańskiego II i niewykluczone, że czymś nas wszystkich zaskoczy. Niemniej jednak, dostrzegając już zaistniałe zbieżności, chciałoby się faktycznie zobaczyć w nim prawosławną odmianę Vaticanum II, charyzmatyczną relekturę tradycji wschodniej, dostrzegalną przecież z wyprzedzeniem w teologii poszukującej, twórczo wiernej dogmatycznemu dziedzictwu swego Kościoła. Doceniając mądrą ostrożność prawosławnych biskupów poszukujących maksymalnego konsensusu ${ }^{73}$, chciałoby się życzyć im także profetycznej odwagi. Dokonana w Duchu Bożym, ożywiającym „literę" doktryn i zwyczajów, omijająca pokusę odwzorowywania zasad „tego świata” przemiana „przez odnawianie umysłu” (por. 2 Kor 3, 6; Rz 12, 2), przyniesie pożytek nie tylko prawosławiu, lecz całej ekumenie - wypada zgodzić się z odnotowaną przez wybitnego badacza problematyki przygotowań Soboru Wszechprawosławnego opinią, że tenże sobór może stanowić krok w kierunku zwołania analogicznego zgromadzenia ogólnochrześcijańskiego ${ }^{74}$. Dodajmy, że podobny ,przedwstępny” krok zrobił już II Sobór Watykański, do którego przygotowania oraz sam jego przebieg rozbudziły wielkie i śmiałe nadzieje ekumeniczne ${ }^{75}$.

Vaticanum II stanowiło dwudziesty pierwszy z soborów uznawanych za powszechne w Kościele rzymskokatolickim, ale pierwszy po

\footnotetext{
${ }^{73}$ Zob. NSO, s. 385.

${ }^{74}$ Zob. tamże, s. 387.

${ }^{75}$ Zob. K. Spink, Brat Roger, założyciel Taizé, dz. cyt., 88.
} 
zdogmatyzowaniu papieskiego prymatu i nieomylności oraz pierwszy przyjmujący „pastoralny” model uroczystego magisterium i niebędący reakcją na ostry kryzys wewnątrzkościelny. Zgromadzenie to, nie odrzucając zdefiniowanych wcześniej dogmatów, przeformułowało całą katolicką doktrynę (oraz zreformowało kościelną praxis) w duchu powrotu do źródeł biblijnych i patrystycznych oraz pierwotnej „przedkonstantyńskiej” prostoty, a także w duchu ekumenicznego otwarcia i dialogu ze wszystkimi „ludźmi dobrej woli"76. Przygotowywany Sobór Wszechprawosławny ma być pierwszym soborem globalnym od czasu siedmiu soborów powszechnych pierwszego tysiąclecia, jednak w sytuacji podziału chrześcijaństwa oraz w związku z prawosławnym uzależnieniem powszechności danego soboru od jego recepcji w takim charakterze przez „pełnię Ludu Bożego" zrezygnowano z określania nowego zgromadzenia mianem soboru powszechnego ${ }^{77}$. Również w tym przypadku idea zwołania soboru nie wiąże się z zaistnieniem dramatycznie kryzysowej sytuacji, lecz jest owocem rozpoznania konieczności określenia się w odnowiony sposób w nowych czasach przez nosicieli żywej tradycji, dających świadectwo wobec innych chrześcijan i świata oraz współpracujących w kontekście wspomnianych relacji na rzecz dobra ludzi i środowiska. Jeśli oba wielkie Kościoły będą żyć coraz pełniej ideą odważnego, ale pokornego, stanowczego, lecz przyjaznego świadectwa o Chrystusie Miłośniku Ludzi, przeżywając swe „pastoralne nawrócenie” ${ }^{78}$, odnajdą się nawzajem w Kościele z wizji Oliviera Clémenta, „niepodzielonym Kościele jutra”, przestrzeni radości i wolności, ,powszechnym i różnorodnym”, sakramentalnym, biblijnym i wspólnotowym ${ }^{79}$.

${ }^{76}$ Por. M. Kita, Kościół Rzymskokatolicki, [w:] W drodze za Chrystusem. Kościoły chrześcijańskie w Polsce mówią o sobie, red. H. Tranda, M. Patalon, Kraków 2009, s. 234.

77 Zob. NSO, s. 128-133.

${ }^{78}$ Por. Aparecida. V Ogólna Konferencja Episkopatów Ameryki Łacińskiej i Karaibów. Dokument końcowy. Jesteśmy uczniami i misjonarzami Jezusa Chrystusa, aby nasze narody miały w Nim życie, 7.2. (365-370), Gubin 2014, s. 180-182.

${ }^{79}$ Zob. O. Clément, Pamiętniki nadziei, dz. cyt., s. 66-68, 205. 
W takim „nawróconym pastoralnie” Kościele ludzi osobiście nawróconych (pierwsze nie istnieje bez drugiego) również zachowujące ważność dla obu stron (oraz dla innych podmiotów z chrześcijańskiej ekumeny) debaty i ustalenia teologiczno-dogmatyczne zyskają nową jakość w przemienionej atmosferze kontaktów. Osobiste nawrócenie ma „potencjał ekumeniczny” - dopiero znając smak i orzeźwiające działanie „żywej wody” Ducha Chrystusa (por. J 4, 14; 7, 37-39), możemy konstruktywnie i z pożytkiem rozmawiać o zaletach (oraz możliwościach ewentualnego łączenia) takich czy innych „systemów irygacyjnych” w postaci naszych tradycji dogmatycznych, liturgiczno-sakramentalnych czy eklezjalnych ${ }^{80}$. Natomiast cały Kościól „nawrócony pastoralnie” w duchu Vaticanum II (i takiego ducha chciałoby się też życzyć Soborowi Wszechprawosławnemu) niesie odnowioną doktrynę i praktykę kościelną jako „lekarstwo miłosierdzia" światu, dla którego staje się ewangelicznym dobrym Samarytaninem - jak przypomina, w ślad za Janem XXIII i Pawłem VI, papież Franciszek. Obecny biskup Rzymu cytuje w tym kontekście słowa drugiego z przywołanych soborowych papieży: „Odrzucono naturalnie błędy, owszem; ponieważ to wymaga miłości nie mniej, niż prawdy; ale dla osób pozostało tylko wezwanie, szacunek i miłość (...) całe to bogactwo doktrynalne jest zwrócone w jednym kierunku: służyć człowiekowi" "1. Duch Vaticanum II, duch Miłosierdzia, sprawia, że Kościół nie żyje dla siebie, tylko dla „strudzonych, którym przychodzi z pomocą przez słowo krzepiące” (por. Iz 50, 4) i w których widzi „braci najmniejszych” swojego Mistrza, Syna Człowieczego (por. Mt 25, 40).

${ }^{80}$ Zob. M. Wichary, Ekumeniczny potencjał doświadczenia nawrócenia, [w:] 0 co chodzi w ekumenizmie? Czym jest dialog? Podstawowe idee Vaticanum II pół wieku później, red. M. Kita, Kraków 2015 , s. 55-58.

${ }^{81}$ Zob. Franciszek, Bulla o Nadzwyczajnym Jubileuszu Miłosierdzia „Misericordiae vultus", nr 4. 


\section{Bibliografia}

Aparecida. V Ogólna Konferencja Episkopatów Ameryki Łacińskiej i Karaibów. Dokument końcowy. Jesteśmy uczniami i misjonarzami Jezusa Chrystusa, aby nasze narody miały w Nim życie, Gubin 2014.

Św. Bonawentura, Droga duszy do Boga i inne traktaty, tłum. C. Napiórkowski, C. Niezgoda, S. Kafel, Poznań 2001.

Bóg żywy. Katechizm Kościoła Prawosławnego, oprac. zespół wiernych prawosławnych, Kraków 2001.

Clément O., Pamiętniki nadziei. Rozmowa z Jean-Claudem Noyer, tłum. M. Żurowska, Poznań 2008;

Clément O., Taizé. Szukanie sensu życia, tłum. M. Prussak, Poznań 1999.

Congar Y., Wierzę w Ducha Świętego, t. 3: Rzeka życia płynie na Wschodzie i na Zachodzie (Ap 22, 1), tłum. L. Rutowska, Warszawa 1996.

Franciszek, Bulla o Nadzwyczajnym Jubileuszu Miłosierdzia „Misericordiae vultus" (11 kwietnia 2015), Wrocław 2015.

Ivereigh A., Prorok. Biografia Franciszka, papieża radykalnego, tłum. M. Masny, Bytom 2015.

Kałużny T., Nowy sobór ogólnoprawosławny. Natura, historia przygotowań, tematyka, Kraków 2008 [=NSO].

Kita M., Boży człowiek Jan, „Znak” (2006) nr 1 (608), s. 99-101.

Kita M., Ekumenizm. Żyć z paradoksami, [w:] Chrześcijaństwo przed nami, red. J. Makowski, J. Salamon, Kraków 2008, s. 111-121.

Kita M., Kościół Rzymskokatolicki, [w:] W drodze za Chrystusem. Kościoły chrześcijańskie w Polsce mówią o sobie, red. H. Tranda, M. Patalon, Kraków 2009, s. 231-261.

Kita M., Logos większy niż ratio. Dwa świadectwa chrześcijańskiego modelu racjonalności u progu epoki wspótczesnej, Kraków 2012.

Kita M., Rosyjski „prawosławny modernizm” i ekumeniczna ortodoksja. Refleksja teologiczno-fundamentalna, „Kultura i Wartości” (2015) nr 14, s. 129-144.

Kołakowski L., Uwaga o modernizmie, „Znak” (2002) nr 7 (566), s. 13-18.

Nie chcemy prawosławnego Vaticanum II (Wywiad Dawida Gospodarka z dr. Pawłem Wróblewskim), http://stacja7.pl/wiara/nie-chcemy-prawoslaw nego-vticanum-ii (13.01.2016).

Puyo J., Życie dla prawdy. Rozmowy z ojcem Congarem, tłum. A. Paygert, Warszawa 1982.

Riccardi A., Una vita complessa, [w:] Atenagora, Chiesa ortodossa e futuro ecumenico. Dialoghi con Olivier Clément, Brescia 1995, s. 367-380. 
Schatz K., Sobory powszechne. Punkty zwrotne w historii Kościoła, tłum. J. Zakrzewski, Kraków 2002.

Sesboüé B., Theobald Ch., Słowo zbawienia [Historia dogmatów 4], tłum. P. Rak, Kraków 2003.

Собрание сочинений Владимира Сергеевича Соловьева, том IV, Санкт-Петербург 1901-1907.

Spink K., Brat Roger, założyciel Taizé, tłum. A. Turowiczowa, Katowice 1992.

Svidercoschi G. F., Inchiesta sul Concilio. Parlano i protagonisti, Roma 1985.

Święcki J., Jan XXIII. Wypróbowany święty, Kraków 2014.

Умное небо. Переписка протоерея Александра Меня с монахиней Иоанной (Ю.Н. Рейтлингер), Москва 2006.

Walicki A., Zarys myśli rosyjskiej od oświecenia do renesansu filozoficzno-religijnego, Kraków 2005.

Ware K., Kościót prawosławny, tłum. W. Misijuk, Białystok 2002.

Wichary M., Ekumeniczny potencjał doświadczenia nawrócenia, [w:] o co chodzi w ekumenizmie? Czym jest dialog? Podstawowe idee Vaticanum II pół wieku później, red. M. Kita, Kraków 2015, s. 45-58.

\section{The Pan-Orthodox Council in Relation to the Second Vatican Council}

\section{SUMMARY}

According to certain expression of metropolite Andrey Sheptystky, the Christian East differs from the West even in cases in which there isn't any differences between them. This rule seems to work also in case of two great ecclesiastical projects of the twentieth century: already realized Second Vatican Council and the Pan-Orthodox Council, still in preparation. Both of them weren't reactions to some theological or disciplinary crises (like earlier councils), but it were a ventures of prudent adaptation of the Church to the modernity - not in the heterodox way of radical modernism but in the way of justified development of living tradition. In both cases similar subjects were proposed to the council fathers: updating of ecclesiastical rules and canons, involvement in the Ecumenical Movement and dialogue with the non-Christian world, consideration of some ecclesiological problems (collegiality and theology of the people of God in the catholic context, spiritual primacy and dependences on mother Churches in the context of eastern autokephalies). However internal 
situations and theological perspectives of both Churches are different, and besides orthodox approach to the considered problems seems much more careful. Of course our sister Church is within her rights to reform herself by her own way but fraternal friendliness orders us to wish her the same spirit of "pastoral conversion" which characterised the reforms of Vaticanum II.

KEYWORDS: ,aggiornamento", Catholicism, council, conciliarity, Eastern Orthodoxy, ecumenism, living tradition, modernism, „pastoral conversion”, reform, renewal, unity

SŁOWA KLUCZOWE: „aggiornamento”, ekumenizm, jedność, katolicyzm, modernizm, „,nawrócenie pastoralne”, odnowa, prawosławie, reforma, sobór, soborowość, żywa tradycja 